J. Clin. Chem. Clin. Biochem.

Vol. 15, 1977, pp. 131-137

\title{
Quantitative Determination of Creatine Kinase Isoenzyme Catalytic Concentrations in Serum Using Immunological Methods ${ }^{1}$ )
}

\author{
By U. Würzburg, N. Hennrich, H.-D. Orth, H. Lang
}

Biochemische Forschung, E. Merck Darmstadt,

W. Prellwitz

Zentrallaboratorium der Medizinischen Universitätskliniken, Mainz,

D. Neumeier, M. Knedel

Institut für Klinische Chemie, Klinikum Großhadern der Universität München

and W. Rick

Institut für Klinische Chemie und Laboratoriumsdiagnostik der Universität Düsseldorf

(Received August 6/October 5, 1976)

Summary: For the determination of creatine kinase isoenzyme catalytic concentrations in serum two methods based on immunological reactions are presented:

One method uses inhibiting antibodies, which selectively block the activity of creatine kinase M subunits ("Inhibition Test"). This test is used for routine measurements of creatine kinase MB catalytic concentration;

Another method uses precipitating antibodies, which allows a quantitative differentiation of creatine kinase isoenzymes MM, MB and BB ("Precipitation Test"). This test is used as a control for the Inhibition Test for the possible presence of creatine kinase $\mathrm{BB}$ activities in doubtful cases.

Procedures, specificity, correlation and application of these methods are discussed.

Quantitative Bestimmung der katalytischen Konzentrationen von Creatinkinase-Isoenzymen im Serum mit Hilfe immunologischer Methoden

Zusammenfassung: Für die Bestimmung der katalytischen Konzentrationen von Creatinkinase-Isoenzymen im Serum werden zwei Mèthoden auf immunologischer Basis beschrieben:

Eine Methode unter Verwendung inhibierender Antikörper, welche dịe Aktivität der Creatinkinase-M-Untereinheiten selektiv hemmen (,Hemmtest"). Diese Methode wird zur routinemäßigen Bestimmung der katalytischen Konzentrationen von Creatinkinase-MB verwendet;

Eine zweite Methode unter Verwendung präzipitierender Antikörper, welche die quantitative Differenzierung der Creatinkinase-Isoenzy me MM, MB und BB erlaubt. Diese Methode wird in Zweifelsfällen als Kontrolle auf eventuelle Creatinkinase-BB-Aktivitäten verwendet.

Die Methoden, ihre Spezifität, Korrelation und Añwendungsmöglichkeiten werden diskutiert.

\section{Introduction}

Creatine kinase (CK; ATP: creatine phosphotransferase, EC 2.7.3.2) in the human organism occurs in the form of dimers of the subunits $M$ and $B$, respectively. Therefore, 3 isoenzymes can be distinguished: creatine kinase MM ("skeletal muscle type"), the hybrid creatine kinase
MB ("myocardial type") and creatine kinase BB ("brain type"). The differentiation of these isoenzymes has gained considerable interest, especially the measurement

1) This work was supported by: Bundesministerium für Forschung und Technologie (BCT 101/123), Deutsche Forschungsgemeinschaft (Schwerpunktprogramm „Enzymdiagnostik“ Pr 66/6). 
of creatine kinase MB catalytic concentration in serum as a parameter of myocardial damage (1).

Several methods for the differentiation of creatine kinase isoenzymes have been published:

Electrophoretic separation in polyacrylamide gel (2), in agar gel (3), in agarose gel (4) und in cellulose acetate (5), with subsequent activity measurement via NADPH fluorescence or via reduction of tetrazolium salts to formazanes.

Chromatographic separation on columns with ion exchange agarose (6) and with ion exchange cellulose (7); on glass beads covered with ion exchange groups (8) or on anion exchange polystyrene ( $8 \mathrm{a}$ ) with batch elution.

High pressure liquid chromatography separation on anion exchange columns (9).

Differential activity measurement in the presence of different substrates (10) and of different sulfhydryl reactivators (11).

Recently the use of precipitating antibodies has been described $(12,13,14,15,16)$.

In the laboratories of our group we have elaborated routine methods for the immunological differentiation of creatine kinase isoenzymes. In the following we present two methods for the measurement of creatine kinase isoenzyme catalytic concentrations in serum:

1. A method using inhibiting antibodies, which measures the activity of creatine kinase B subunits present in the sample ("Inhibition Test")' For this test inhibiting antibodies (Inh-CK-M-antibodies) are employed, which selectively and quantitatively block the activity of creatine kinase $\mathrm{M}$ subunits. This test is used for the measurement of serum creatine kinase MB catalytic concentrations.

2. A method using precipitating antibodies, which allows quantitative differentiation of creatine kinase isoenzymes MM, MB, and BB, respectively ("Precipitation Test"). In this test the precipitating antibodies anti-Creatinkinase-MM and anti-Creatinkinase-BB are employed. This test, in addition to its use in the differentiation of all creatine kinase isoenzymes, is proposed as a control in cases of suspected creatine kinase $\mathrm{BB}$ activity in combination with the Inhibition Test.

Procedure, specificity, correlation and application of these methods are discussed.

\section{Experimental Procedures and Results}

\section{Inhibition Test}

\section{Reagents}

Preparation of creatine kinase MM human by a modified procedure according to Keutel et al. (17). Specific activity of the enzyme used for immunization $=320 \mathrm{U} / \mathrm{mg}$ protein. Preparation of Inh-CK-M-antibodies according to Würżburg et al. (18) and Neumeier et al. (19) in goats. Reagents and method for measurement of creatine kinase catalytic concentration according to the Recommendations of the German Society for Clinical Chemistry (20). Reagents are used in form of a test kit containing a quantity of Inh-CK-M-antibodies, which inhibit quantitatively per test about $1000 \mathrm{U} / \mathrm{l}$, at least 800 U/1, creatine kinase MM (Merck-1-Test CK-MB, No. 14 300).

\section{Procedure}

Equilibrate serum and reagents at $25^{\circ} \mathrm{C}$. Add $2.00 \mathrm{ml}$ buffer substrate solution plus $0.10 \mathrm{ml}$ non hemolytic serum to one bottle of coenzyme-enzyme-antibody reagent. Mix and incubate for 7 minutes at $25^{\circ} \mathrm{C}$. Place in a $1 \mathrm{~cm}$ cuvette and record absorbance for 5 minutes at $340 \mathrm{~nm}$. Prepare and measure a reagent blank without serum. Dilute sera with creatine kinase catalytic concentrations over $800 \mathrm{U} / 1$ with $9 \mathrm{~g} / 1$ sodium chloride solution to catalytic concentrations below $800 \mathrm{U} / \mathrm{l}$. Calculate activity from $\Delta \mathrm{A}$ per 5 minutes after deduction of $\Delta \mathrm{A}$ of the corresponding blank by multiplication with the factor 667. This factor is derived as follows: Creatine kinase $\mathrm{B}$ catalytic concentration =

$$
\begin{aligned}
& \Delta \mathrm{A} / 5 \min \times \frac{\text { test volume }}{\text { sample volume }} \times \frac{10^{6}}{\epsilon \cdot \mathrm{d} \cdot 5}[\mathrm{U} / 1]= \\
& \Delta \mathrm{A} / 5 \min \times \frac{2.1}{0.1} \times \frac{10^{6}}{6300 \cdot 1 \cdot 5}[\mathrm{U} / 1] .
\end{aligned}
$$

The revised value for $\mathrm{NADPH}_{340 \mathrm{~nm}}$ is $6.3001 \cdot \mathrm{mor}^{-1} \cdot \mathrm{cm}^{-1}$ (21). The result gives the catalytic concentration of CK-B subuinits present in the sample, if the catalytic concentration is to be expressed as CK-MB, multiply the activity with the factor of 2 .

\section{Model experiments}

To demonstrate the degree of inhibition of creatine kinase isoenzymes by Inh-CK-M-antibodies, model experiments are performed on inactivated human sera, to which measured amounts of purified human creatine kinase isoenzymes are added. For the preparation and specific activities of creatine kinase $\mathrm{MM}$ and $\mathrm{BB}$ used, see chapter "Precipitation test, reagents". Creatine kinase $\mathrm{MB}$ is prepared by reversible dissociation of an equal mixture of creatine kinase $\mathrm{MM}$ plus $\mathrm{BB}$ in $3.6 \mathrm{~mol} / 1$ guanidinium chloride followed by chromatographic separation on DEAE agarose. Specific activity of the creatine kinase $\mathrm{MB}$ preparation used $=330 \mathrm{U} / \mathrm{mg}$ protein. The experiments are 5-fold determinations with an intraserial CV of $1.99 \%$. Table 1 contains the results of these measurements. Within the limits of error the following percentage of activity inhibition is obtained: creatine kinase $\mathrm{MM}=100 \%$, creatine kinase $\mathrm{MB}=50 \%$, creatine kinase $\mathrm{BB}=0 \%$. These figures are valid in the total range of catalytic concentrations for which this test has been conceived.

These figures, however, are mean values. Considering the $\pm 2 \mathrm{SD}$ range, the inhibition of creatine kinase $\mathrm{MB}$ activity by Inh-CK-M-antibodies is between 45 and $56 \%$ (not taking into account the larger variation with the value of $18 \mathrm{U} / 1 \mathrm{CK}-\mathrm{MB}$ ). This range possibly represents not only methodological errors, but also a difference in the specific activity against creatine phosphate of creatine kinase $M$ and $B$ subunits, respectively, or a possible allosteric effect on the creatine kinase $B$ sub. unit within the MB dimer effected by the binding of the antibody to the $M$ subunit. This problem is being investigated.

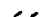


Tab. 1. Inhibition of creatine kinase isoenzyme catalytic concentrations by inhibiting creatine kinase $M$ antibodies. Inactivated human sera with addition of purified human creatine kinase isoenzymes. Mean \pm 1 SD from 5 fold determinations.

\begin{tabular}{lcc}
\hline Isoenzy me & $\begin{array}{l}\text { catalytic concentrations after } \\
\text { addition of human isoenzymes } \\
{[\mathrm{U} / 1]}\end{array}$ & $\begin{array}{l}\text { Residual catalytic concentrations after } \\
\text { incubation with Inh-CK-M-antibody } \\
\text { [U/l] }\end{array}$ \\
\hline CK-MM & $98 \pm 1.9$ & $0.3 \pm 2.1$ \\
& $1043 \pm 22$ & $0.5 \pm 2.5$ \\
CK-MB & $18 \pm 0.9$ & $8.7 \pm 0.9$ \\
& $37 \pm 0.7$ & $18 \pm 0.8$ \\
& $103 \pm 2.0$ & $53 \pm 1.7$ \\
CK-BB & $410 \pm 7.8$ & $206 \pm 6.2$ \\
\hline
\end{tabular}

\section{Further characterization of inhibiting antibodies}

The inhibitory action of Inh-CK-M-antibodies can be shown to be a primary interaction with the enzyme molecule (no precipitation) by use of monovalent antibody fragments. Fab and $\mathrm{Fc}$ fragments are produced from Inh-CK-M-antibody by a modified procedure according to Porter (22). The inhibition of creatine kinase MM activity by Inh-CK-M-antibody, $\mathrm{Fab}$ and $\mathrm{Fc}$, respectively, was measured at different concentrations of these proteins. The results are presented in figure 1 . Fab fragments inhibit creatine kinase MM activity to $100 \%$, the inhibition characteristics being the same as with complete antibodies. Fc fragments yield no inhibition of creatine kinase MM activity, as is to be expected.

The influence of the animal species used to raise antibodies on the specificity of Inh-CK-M-antibodies is

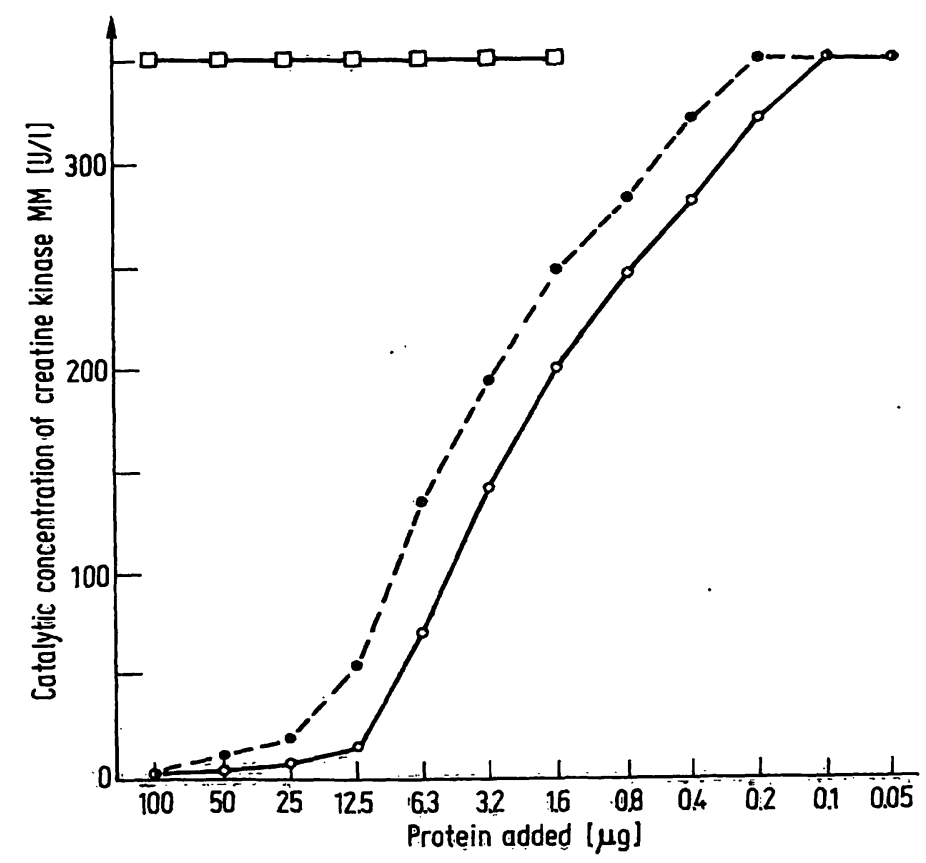

Fig. 1. Inhibition of creatine kinase MM catalytic concentration by Inh-CK-M-antibodies and antibody fragments.

---o Inh-CK-M-antibody IgG

0 - Fab fragments

$\square$ - Fc fragments shown in figure 2. The inhibition of creatine kinase MB activity by antibodies from different animal species is plotted against the antibody concentration. Only goat antibodies yield $50 \%$ inhibition of creatine kinase $\mathrm{MB}$ activity, this value being constant over a broad concentration range. Rabbit and sheep antibodies at high concentrations inhibit creatine kinase MB activity by more than $50 \%$, which means that besides creatine kinase $M$ subunit activity, B subunit activity is also partially inhibited.

The influence of the antigen used for immunization on the specificity of the resulting antibodies is shown in figure 3. The inhibition of creatine kinase MB activity is plotted against the antibody concentration. Besides human creatine kinase MM, creatine kinase MM from rhesus skeletal muscle also gives rise to antibodies in the goat, which inhibit human creatine kinase MB by $50 \%$. Antibodies raised against creatine kinase MM from

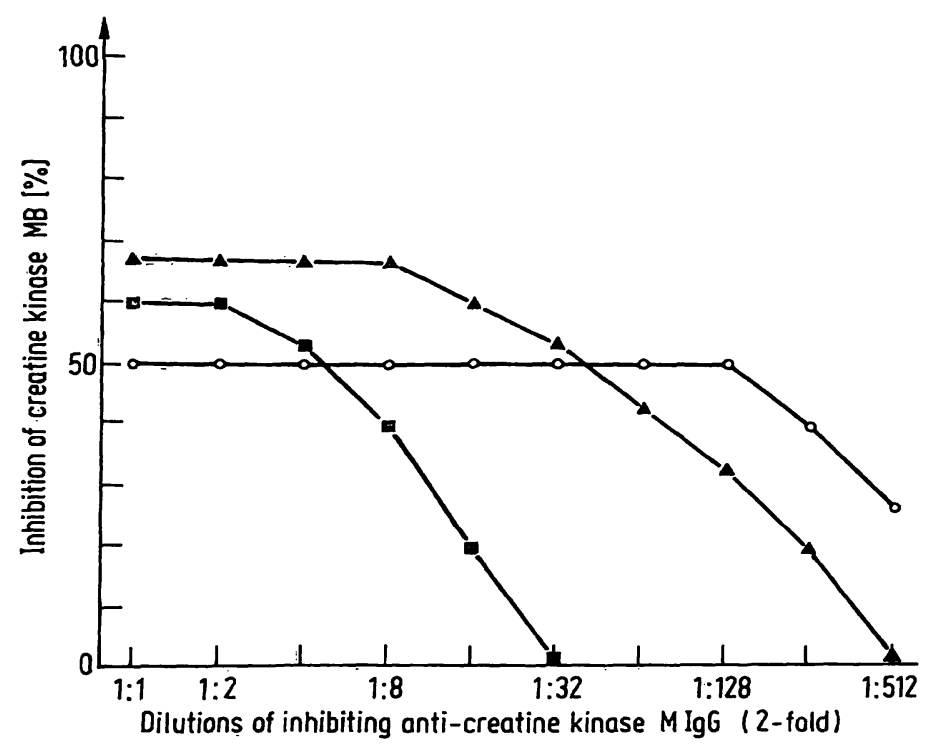

Fig. 2. Inhibition of creatine kinase MB (catalytic concentration $450 \mathrm{U} / \mathrm{l}$ ) by anti-creatine kinase-M-antibodies raised in different animal species.

0-0 goat-anti-human-CK-MM IgG

- - rabbit-anti-human-CK-MM IgG

__ sheep-anti-human-CK-MM IgG 


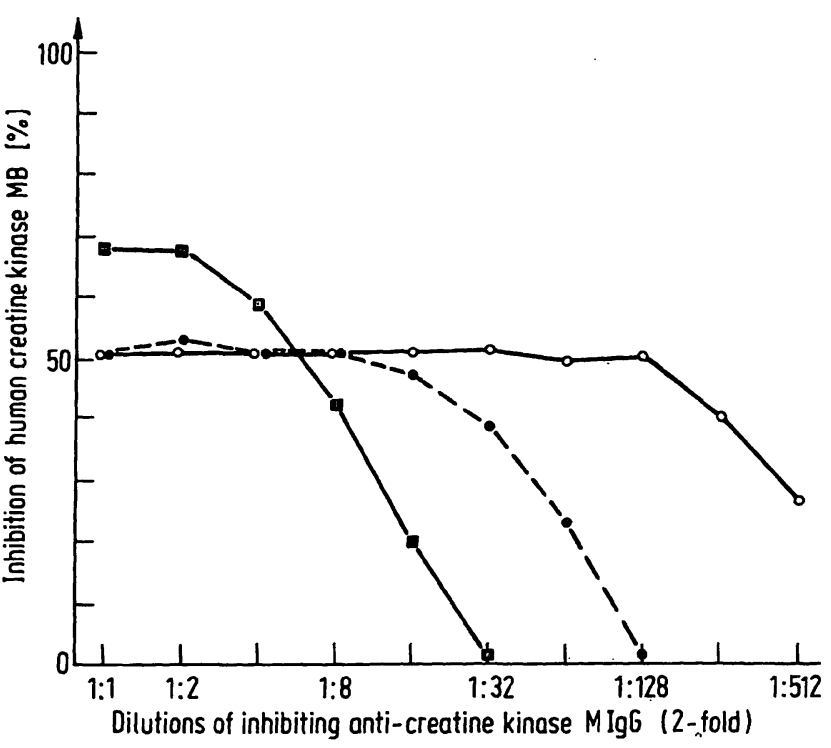

Fig. 3. Inhibition of creatine kinase $\mathrm{MB}$ by anti-creatine kinase$M$-antibodies raised against antigens from different species.

$\circ-0$ goat-anti-human-CK-MM IgG

$\bullet-\cdot-$ goat-anti-rhesus-CK-MM IgG

- - rabbit-anti-rhesus-CK-MM IgG

other species (rabbit, pig) give no adequate cross reaction with the human enzyme (not shown in the figure).

\section{Precision}

Measurements of creatine kinase MB catalytic concentration in control samples (pooled sera of patients with myocardial infarction and myocardial extracts) give the following results:

Intraserial precision:

$$
\begin{aligned}
& \mathrm{CV}=13 \% \text { at } 13 \mathrm{U} / 1, \\
& \mathrm{CV}=5 \% \text { at } 32 \mathrm{U} / \mathrm{l}, \\
& \mathrm{CV}=2 \% \text { at } 72 \mathrm{U} / 1(18)
\end{aligned}
$$

Precision from day to day:

$$
\begin{aligned}
& \bar{x}=36 \mathrm{U} / 1, \mathrm{SD}=3.0 \mathrm{U} / \mathrm{l}, \mathrm{CV}=8.3 \%, \mathrm{n}=27(18), \\
& \overline{\mathrm{x}}=46 \mathrm{U} / \mathrm{l}, \mathrm{SD}=2.5 \mathrm{U} / \mathrm{l}, \mathrm{CV}=5.5 \%, \mathrm{n}=14(19)
\end{aligned}
$$

Long term precision in serum:

$$
\bar{x}=33 \mathrm{U} / 1, \mathrm{SD}=5.1 \mathrm{U} / 1, \mathrm{CV}=6.9 \%, \mathrm{n}=94(23)
$$

Long term precision in myocardial extracts:

$$
\overline{\mathrm{x}}=174 \mathrm{U} / 1, \mathrm{SD}=11.8 \mathrm{U} / \mathrm{l}, \mathrm{CV}=6,7 \%, \mathrm{n}=41
$$

Performing the test with double determinations plus deduction of the reagent blank, creatine kinase $\mathrm{MB}$ catalytic concentrations of $3 \mathrm{U} / 1$ can be distinguished from zero level (95\% niveau) (18). Performing the test with single determinations without measurement of the reagent blank, creatine kinase MB catalytic concentrations of about $10 \mathrm{U} / 1$ can be distinguished from background level.

\section{Precipitation Test}

\section{Reagents}

Creatine kinase MM from skeletal muscle and of creatine kinase BB from bran tissue are prepared by a modified version of the method according to Keutel et al. (17). Specific activities of creatine kinase $\mathrm{MM}=320 \mathrm{U} / \mathrm{mg}$ protein, of creatine kinase $\mathrm{BB}=292 \mathrm{U} / \mathrm{mg}$ protein. Precipitating antisera are prepared according to Neumeier et al. (16). The antisera are anti-Creatinkinase-MM (vom Hammel) (Merck No. 11 642) and anti-Creatinkinase-BB (vom Hammel) (Merck No. 11 643).

Borate buffer $\mathrm{pH}$ 8.4: dissolve $0.1 \mathrm{~mol}$ boric acid, $0.025 \mathrm{~mol}$ disodium tetraborate $x 10 \mathrm{H}_{2} \mathrm{O}$ and $0.075 \mathrm{~mol} \mathrm{NaCl}$ in distilled water to give 1 liter. Polyethylene gilycol/n-acetyl cysteine (PEG-NAC): dissolve $12 \mathrm{~g}$ polyethylene gly col 6000 (Merck Schuchardt No. 807491 ) and $0.653 \mathrm{~g} \mathrm{~N}$-acetyl cysteine (Merck No. 12 422) in $100 \mathrm{ml}$ borate buffer. Reagents and method for measure ment of creatine kinase catalytic concentration are according to the Recommendations of the German Society for Clinical Chemistry (20) in the form of a test kit (Merck-1-Test CK No. 3381).

\section{Procedure}

The precipitation test is performed according to Prellwitz et al. (23) in a modification of the procedure described by Jockers et al. $(14,15)$, Prellwitz et al. (13) and Neumeier et al. (16). The principle of the test is outlined in figure 4 . Samples with high creatine kinase catalytic concentrations are diluted with borate buffer to a total creatine kinase catalytic concentration in the range 70-90 U/1. Pipette tests according to table 2 . Incubate samples 1 hour at $37^{\circ} \mathrm{C}$ plus overnight at $4^{\circ} \mathrm{C}$. Centrifuge samples at high speed. Take $0.10 \mathrm{ml}$ from clear supernatants for measurement in 3 fold determina-

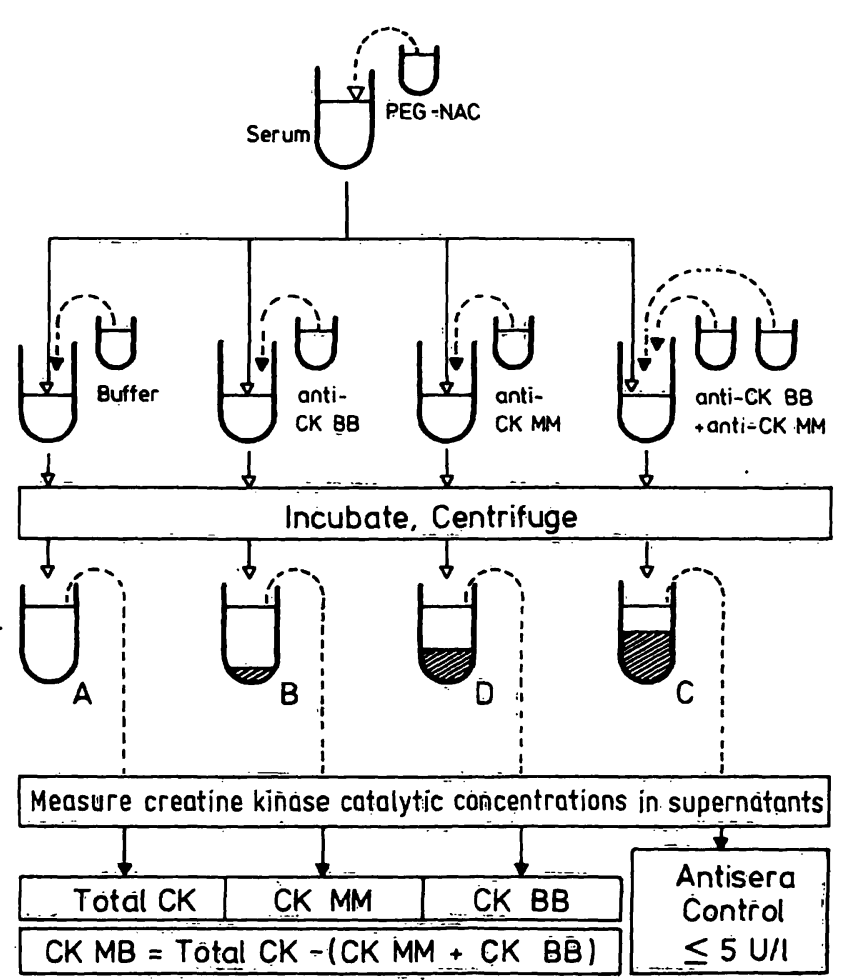

Fig. 4. Scheme for measurement of creatine kinase isoenzyme catalytic concentrations with the Precipitation Test. PEG-NAC = Polyethylëne glycol-N-acetyl cysteine solution, see text.

CK = creatine kinase. 
tions. Calculate catalytic concentrations of the isoenzymes according to the following scheme (see tab. 2):

$A \quad=C K-M M+C K-M B+C K-B B=$ total creatine kinase

Supernatant $B=C K-M M$

Supernatant $D=C K-B B$

Total CK $-(C K-M M+C K-B B)=C K-M B$ albumin. For the preparation and specific activities of the creatine kinase isoenzymes used, see sections "Precipitation Test, reagents" and "Inhibition Test, model experiments". The results are summarized in figure 5. The isoenzyme activities added to the different mixtures are recovered within the limits of experimental error.

Tab. 2. Pipetting scheme for measurement of creatine kinase isoenzyme catalytic concentrations with the Precipitation Test.

\begin{tabular}{|c|c|c|c|c|c|c|c|}
\hline \multirow{2}{*}{\multicolumn{2}{|c|}{$\begin{array}{l}\text { A } \\
\text { Measurement of total creatine } \\
\text { kinase catalytic concentrations }\end{array}$}} & \multirow{2}{*}{\multicolumn{2}{|c|}{$\begin{array}{l}\text { B } \\
\text { Measurement of supernatant } \\
\text { activity after precipitation } \\
\text { with anti-CK-BB }\end{array}$}} & \multirow{2}{*}{\multicolumn{2}{|c|}{$\begin{array}{l}\text { C } \\
\text { Control of } \\
\text { complete precipitation }\end{array}$}} & \multirow{2}{*}{\multicolumn{2}{|c|}{$\begin{array}{l}\text { D } \\
\text { Check for eventual } \\
\text { CK-BB activity }\end{array}$}} \\
\hline & & & & & & & \\
\hline $\begin{array}{l}\text { Serum } \\
\text { PEG-NAC } \\
\text { Borate buffer }\end{array}$ & $\begin{array}{l}0.5 \mathrm{ml} \\
0.2 \mathrm{ml} \\
0.1 \mathrm{ml}\end{array}$ & $\begin{array}{l}\text { Serum } \\
\text { PEG-NAC } \\
\text { anti-CK-BB }\end{array}$ & $\begin{array}{l}0.5 \mathrm{ml} \\
0.2 \mathrm{ml} \\
0.1 \mathrm{ml}\end{array}$ & $\begin{array}{l}\text { Serum } \\
\text { PEG-NAC } \\
\text { anti-CK-MM } \\
\text { anti-CK-BB }\end{array}$ & $\begin{array}{l}0.5 \mathrm{ml} \\
0.2 \mathrm{ml} \\
0.05 \mathrm{ml} \\
0.05 \mathrm{ml}\end{array}$ & $\begin{array}{l}\text { Serum } \\
\text { PEG-NAC } \\
\text { anti-CK-MM }\end{array}$ & $\begin{array}{l}0.5 \mathrm{ml} \\
0.2 \mathrm{ml} \\
0.1 \mathrm{ml}\end{array}$ \\
\hline
\end{tabular}

Final concentration of polyethylene glycol (PEG) in test $=30 \mathrm{~g} / 1$

Final concentration of N-Acetyl cysteine (NAC) in test $=10 \mathrm{mmol} / \mathrm{l}$

Dilution factor

\section{Model Experiments}

Model experiments showing the differentiation of reatine kinase isoenzymes are performed in solutions of purified human isoenzymes in $50 \mathrm{~g} / \mathrm{l}$ human serum

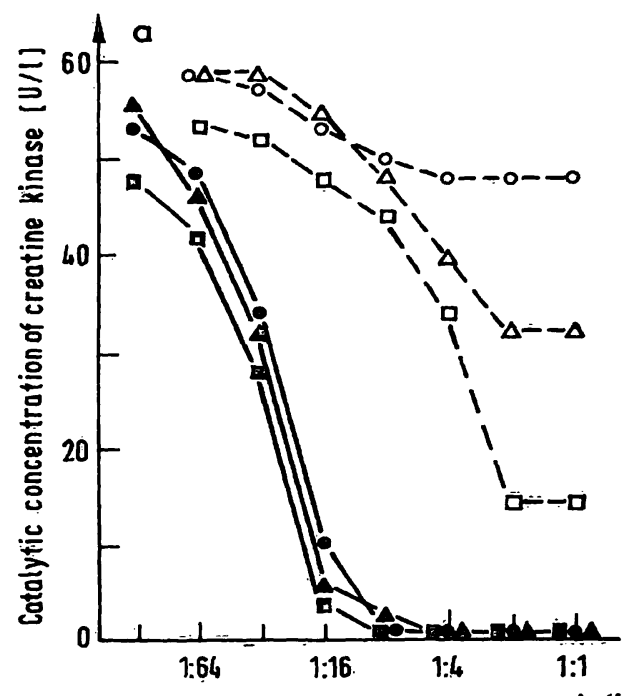

\section{Precision}

Measurement of creatine kinase MM catalytic concentration in serum: $\overline{\mathrm{x}}=357 \mathrm{U} / \mathrm{l}, \mathrm{SD}=12.5 \mathrm{U} / \mathrm{l}, \mathrm{CV}=3.5 \%$,

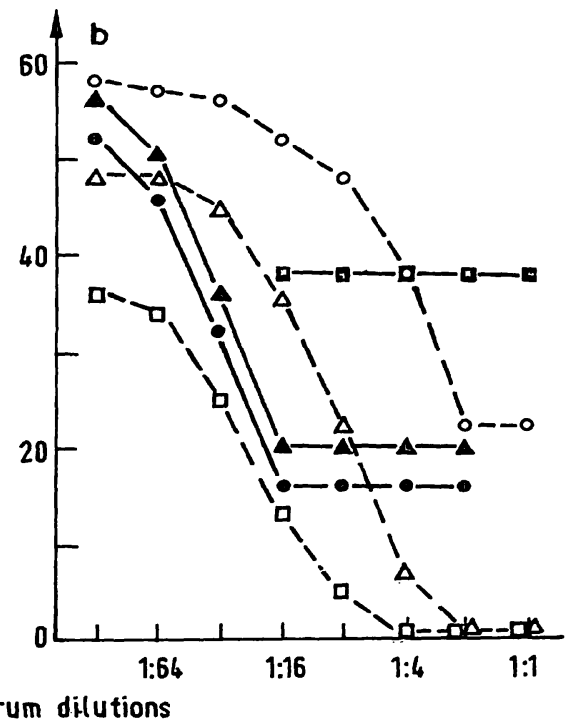

Fig. 5. Immuno precipitation of creatine kinase isoenżyme mixtures with the Precipitation Test.

a. Mixtures of creatine kinase $M M$ and $M B$ in different ratios.

catalytic concentrations added [U/1]

CK-MM

\section{CK-MB}

48

32

14

\section{2}

28

40 catalytic concentrations in supernatant after precipitation with anti-CK-MM anti-CK-BB

-1$0--0$

$\Delta--\Delta$

口---

b. Mixtures containing creatine kinase BB.

catalyțic concentrations addẹ [U/1]

CK-MM

CK-MB

CK-BB

22

$-$

20

28
16.

20

38 catalytic concentrations in supernatant after precipitation with anti-CK-MM anti-CK-BB

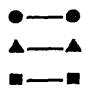


$\mathrm{n}=10$ (14). Measurement of creatine kinase MB catalytic concentrations in serum: $\mathrm{CV}$ in the range of $10-20 \%(14,16)$, this high value resulting from calculation of catalytic concentrations as difference values.

\section{Comparison of Methods}

Parallel measurements with the Inhibition Test and the Precipitation Test of creatine kinase MB catalytic concentrations are performed in sera of patients suffering from myocardial infarction and other diseases. The results are presented as a correlation plot in figure 6 . The values measured with the Inhibition Test average $11 \%$ higher than the values measured with the Precipitation Test.

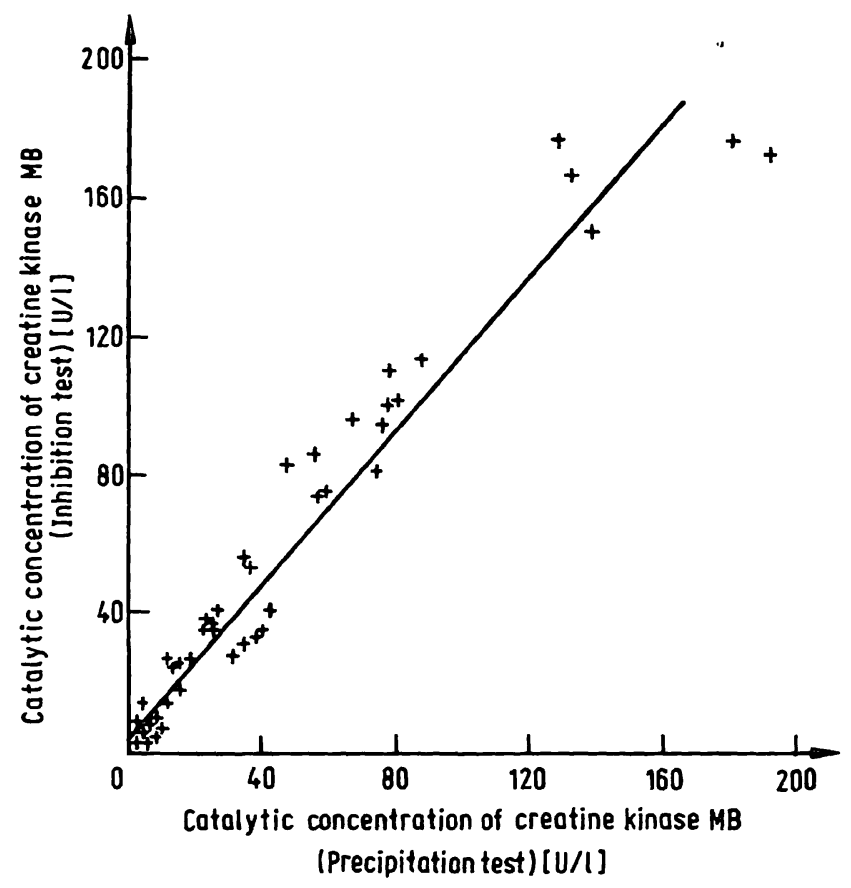

Fig. 6. Correlation of creatine kinase MB catalytic concentrations measured in parallel with Inhibition Test and Precipitation Test.

Human sera, $\mathrm{n}=73$

$y=3.90+1.11 x$

$s_{y x}= \pm 11 \mathrm{U} / 1, r=0.97$.

\section{Discussion}

The two methods described here for measurement of creatine kinase isoenzyme catalytic concentrations utilize different aspects of the antigen-antibody-reaction:

The Inhibition Test is based on the primary immuniological reaction, the binding of antibodies to the enzyme protein with concurrent inhibition of enzymatic activity. This reaction mechanism has been proved by use of monovalent antibody fragments, which show equal enzyme inhibition. Utilization of the primary immunological reaction leads to a short reaction time. Because the activity of all creatine kinase B subunits present in the sample is measured after inhibition of the creatine kinase $M$ subunit activity, differentiation between creatine kinase $\mathrm{MB}$ and $\mathrm{BB}$ is not possible.

From the aspect of methodology two points are important for the Inhibition Test: With respect to the reagents, it is possible to use antisera raised against the enzyme from rhesus monkey skeletal muscle, as well as antibodies against human creatine kinase MM. Considering test precision, the small absorbance differences measured in sera with low creatine kinase MB catalytic concentrations necessitate careful control of the known factors interfering with creatine kinase catalytic concentration measurements (e. g. hemolysis).

The Precipitation Test represents in immunological terms a secondary reaction, the formation of a cross linked insoluble immuno precipitate. This leads to a long reaction time, but the differentiation of all creatine kinase isoenzymes is possible. Measurement of creatine kinase $\mathrm{MM}$ and $\mathrm{BB}$ catalytic concentrations yields results with standard deviations in the usual range; measurement of creatine kinase MB catalytic concentrations, however, yields results with very large standard deviation, caused by error multiplication in the difference calculation.

The principles of both tests outlined above lead to their application in creatine kinase isoenzyme differentiation: The Inhibition Test is used for fast and quantitative measurement of creatine kinase $\mathrm{MB}$ catalytic concentrations in serum. Prerequisite for this use is the fact that creatine kinase BB activities never or only rarely occur in serum. The debate about the frequency of occurrence of creatine kinase BB activities in serum (23-33) is approaching the point where it is accepted that creatine kinase BB activities in serum are found only in exceptional cases. In the authors' investigations, confirmed creatine kinase BB activities have been observed in 2 out of about 15000 routine measurements. The specificity of the Inhibition Test will not be impaired significantly, therefore, by creatine kinase BB. The Precipitation Test can be used in doubtful cases as a safety check on the Inhibition Test. Because the precipitating antiserum anti-CK-MM will precipitate creatine kinase MM plus MB, it is possible to check with a single precipitation, whether a suspected serum sample contains creatine kinase BB activity or not.

The measured correlation of both methods is sufficient for this suggested use of the Precipitation Test as safety check for creatine kinase BB. In the Precipitation Test all sera showing total creatine kinase catalytic concentrations over $90 \mathrm{U} / 1$ have to be diluted. In view of the present knowledge about the variation of creatine kinase catalytic concentrations after dilution of sera, a better correlation could not therefore be expected. 
The results of measurements of creatine kinase isoenzyme catalytic concentrations in sera of patients with different diseases using the tests described are being published separately by several groups of authors (13-16, $18,19,23,24,34,35)$.

\section{References}

1. Roberts, R. \& Sobel, B. E. (1976), Hosp. Pract. 11, 55-62.

2. Smith, A. F. (1972), Clin. Chim. Acta 39, 351-359.

3. Roc, C. R., Limbird, L. E., Wagner, G. S. \& Nerenberg,

S. T. (1972), J. Lab. Clin. Med. 80, 577-590.

4. Somer, H. \& Konttinen, A. (1972), Clin. Chim. Acta 36 , $531-536$.

5. Roberts, R., Henry, P. D., Witteveen, S. A. G. J. \& Sobel, B. E. (1974), Am. J. Cardiol. 33, 650-654.

6. Mercer, D. W. (1974), Clin. Chem. 20, 36-40.

7. Nealon, D. A. \& Henderson, A. R. (1975), Clin. Chem. $21,392-397$.

8. Henry, P. D., Roberts, R. \& Sobel, B. E. (1975), Clin. Chem. 21, 844-849.

8a. Morin, L. G. (1976), Clin. Chem. 22, 92-97.

9. Kudirka, P. J., Busby, M. G., Carey, R. N. \& Toren, E. C. jr. (1975), Clin. Chem. 21, 450-452.

10. Witteveen, S. A. G. J., Sobel, B. E. \& DeLuca, M. (1974), Proc. Nat. Acad. Sci. U.S.A. 71, 1384-1387.

11. Rao, P. S., Lukes, J. J., Ayres, S. M. \& Mueller, H. (1975), Clin. Chem. 21, 1612-1618.

12. Pfleiderer, G. (1975), in Zusammenarbeit von Klinik und Klinischer Chemie (Lang, H., Rick, W. \& Róka, L., eds.) p. 197-223, Springer Heidelberg.

13. Prellwitz, W., Gempp-Friedrich, W. \& Lang, H. (1975), l. c. 12. p. 224-250.

14. Jockers-Wretou, E., Grabert, K. \& Pfleiderer, G. (1975), this J. 13, 85-88.

15. Jockers-Wretou, E. \& Pfleiderer, G. (1975), Clin. Chim. Acta 58, 223-232.

16. Neumeier, D., Knedel, M., Würzburg, U., Hennrich, N. \& Lang, H. (1975), Klin. Wochenschr. 53, 329-333.

17. Keutel, H. J., Okabe, K., Jacobs, H. K., Ziter, F., Maland, L. \& Kuby, S. A. (1972), Arch. Bioch. Biophys. 150, 648-678.

18. Würzburg, U., Hennrich, N., Lang, H., Prellwitz, W., Neumeier, D. \& Knedel, M. (1976), Klin. Wochenschr. 54, $357-360$.

\section{Acknowledgement}

The skilful technical help of Miss A. Gröninger, Mr. H. Hubert, Miss B. Siegele, Miss $M$. Stechert and Miss $B$. Wolter is greatly appreciated.

19. Neumeier, D., Prellwitz, W., Würzburg, U., Brundobler, M., Olbermann, M., Just, H.-J., Knedel, M. \& Lang, H. (1976), Clin. Chim. Acta 73, 445-451.

20. Recommendations of the German Society for Clinical Chemistry: Standardisation of methods for the estimation of enzyme activities in biological fluids (1970), this. J. 8, $658-660$; (1972), this J. 10, 182-192.

21. Bergmeyer, H. U. (1975), this J. 13, 507-508.

22. Porter, R. R. (1959), Biochem. J. 73, 119-126.

23. Prellwitz, W., Neumeier, D., Knedel, M., Lang, H., Würzburg, U., Schönborn, H. \& Schuster, H. P. (1976), Dtsch. Med. Wochenschr. 101, 983-988.

24. Jockers-Wretou, E., Grabert, K., Müller, E. \& Pfleiderer, G. (1976), Clin. Chim. Acta, in press.

25. Nealon, D. A. \& Henderson, A. R. (1975), Clin. Chem. 21, 1663-1666.

26. Coolen, R. B., Pragay, D. A. \& Chilcote, M. E. (1975), Clin. Chem. 21, 976.

27. Byrnes, A. C. \& Alter, S. (1975), Clin. Chem. 21, 1845.

28. Henry, P. D., Roberts, R. \& Sobel, B. E. (1975), Clin. Chem. 21, 1845-1846.

29. Galen, R. S. (1976), Clin. Chem. 22, 120.

30. Itano, M. (1976), Am. J. Clin. Pathol. 65, 351-355.

31. Rick, W. (1975), 1. c. 12 , p. 245.

32. Mercer, D. (1976), Clin. Chem. 22, 552-554.

33. Peter, H.-J., Zapf, J., Froesch, E. R., Eppenberger, H., Bernhard, K. \& Hossli, G. (1976), Schweiz. Med. Wochenschr. 106, 987-991.

34. Prellwitz, W. \& Neumeier, D. (1976), Internist 17, 436-444.

35. Reichart, B., Kemkes, B., Brunner, L., Klinner, W., Neumeier, D. \& Lang, H. (1977), Klin. Wochenschr., in press.

Dr. H. Lang Biochemical Research E. Merck P. O. Box 4119

D-6100 Darmstadt 1 
